Oceanography in support to indicator reporting

J. A. Johannessen et al.

\section{Operational oceanography in support to indicator reporting}

Title Page

Abstract

Introduction

Conclusions

References

J. A. Johannessen ${ }^{1,2}$, G. Coppini ${ }^{3,4}$, F. Soulat $^{5}$, and G. Larnicol ${ }^{5}$

${ }^{1}$ Nansen Environmental and Remote Sensing Center, Bergen, Norway

${ }^{2}$ Geophysical Institute, University of Bergen, Norway

${ }^{3}$ Istituto Nazionale di Geofisica e Vulcanologia, Bologna, Italy

${ }^{4}$ Università di Bologna (UNIBO), Ravenna, Italy

${ }^{5}$ Collecte Localisation Satellites (CLS), Ramonville Saint-Agne, France

Received: 31 July 2009 - Accepted: 11 August 2009 - Published: 18 January 2010

Correspondence to: J. A. Johannessen (johnny.johannessen @nersc.no)

Published by Copernicus Publications on behalf of the European Geosciences Union.
Tables

14

4

Back Figures

DI

$>$

Close

Full Screen / Esc

Printer-friendly Version

Interactive Discussion 


\section{Abstract}

Operational Oceanography $(\mathrm{OO})$ has now emerged to a stage that allows the design, development and execution of marine core services tailored to user requirements. As such it is also feasible to provide routine production of environmental and climate 5 indicators. Indicators are synthetic indices of environmental changes at various temporal and spatial scales. In this paper we outline the possible contribution and strengthening of existing indicator reporting based on $\mathrm{OO}$ products followed by a discussion of the relevance of such improved reporting for marine environmental policy implementation and regulation. In particular, it capitalizes on the main achievements of the Marine Environment and Security of the European Area (MERSEA) project, the outcome of a European Marine Monitoring and Assessment (EMMA) workshop on the connection between operational oceanography and the European Marine Strategy (EMS) Directive and the regular European Environmental Agency (EEA) assessment reports.

\section{Introduction}

Operational Oceanography (OO), such as implemented by MyOcean (http://www. myocean.eu.org) will be at the basis of the GMES (http://www.gmes.info) Fast Track Service, notably the Marine Core Service (MCS) for the protection and management of the marine environment. It provides homogeneous 3 dimensional descriptions of temporal and spatial variability and dynamics of the ocean that complement, combine and extend in-situ and satellite observations. It offers information and data delivery for hindcast and reanalyses, nowcast and forecast purposes. As such it may be used to support indicator reporting and help to explain how the quality of the marine environment changes over time and varies spatially, both for European Seas and other regional seas. As initiated in the Marine Environment and Security of the European Area (MERSEA http://www.mersea.eu.org) integrated project (Desaubies, 2009) and
OSD

$7,121-141,2010$

Oceanography in support to indicator reporting

J. A. Johannessen et al.

\section{Title Page}

Abstract

\section{Full Screen / Esc}

Printer-friendly Version

Interactive Discussion 
slightly modified and extended in MyOcean project (Bahurel et al., 2009) the global and regional data assimilation systems covers:

OSD

- the global and Atlantic oceans

- the high latitude Nordic and Arctic Seas

- the Baltic Sea

- the NW European Shelf

- the Iberian region, Bay of Biscay and Irish Seas

- the Mediterranean, and

- the Black Sea.

10 This paper addresses selected variables (see Table 1) produced during the targeted demonstration phase of the MERSEA Integrated Project funded by EU FP6 and ETC-W (European Topic Center for Water) consortium funded by EEA (Coppini et al., 2008). These are chosen among those highlighted by the EEA-EMMA (European Marine Monitoring and Assessment) led OO Workshop "Towards a converging framework 15 for monitoring and assessment of European marine waters - Synthesis Report 1: Operational Oceanography" in Copenhagen, 23-24 October 2006 (EEA, 2006) to be considered potentially relevant in support to indicator reporting.

Indicators are used by international environmental agencies like the European Environment Agency (EEA, http://themes.eea.europa.eu/indicators/) and conventions 20 such as for instance (HELCOM, http://www.helcom.fi/environment2/ifs/en_GB/cover/) for their regular reporting on the assessment of the environment (i.e. EEA, 2004).

In particular the arrangement of the assimilation system and modeling forecasting centre in MyOcean as listed above are providing a very good match to the boundaries for the regional conventions (including AMAP, HELCOM, OSPAR, UNEP/MAP and
BSEP) established for the European Seas as shown in Fig. 1.
7, 121-141, 2010

Oceanography in support to indicator reporting

J. A. Johannessen et al.

Title Page

Abstract

Introduction

Conclusions

Tables

References

Figures

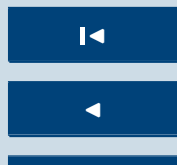

$\Delta$

Back

Close

Full Screen / Esc

Printer-friendly Version

Interactive Discussion 
By combining properly validated models and observations, as now emerging in operational oceanography systems, homogenous fields of temporal and spatial information can be regularly produced. Such fields make interpolation from more scarcely distributed observation points more reliable. Consequently better 5 understanding and quantitative characterization of the spatial as well as the temporal variability can be achieved. This in turn, would provide clear benefit to indicator reporting and regular state of the ocean assessments.

\section{Indicator selections and demonstration of products}

Environmental indicators reflect trends in the state of the environment and monitor 10 eventual progress made in realising environmental policy targets and provide insight into the state and dynamics of the environment (Smeets and Weterings, 1999). A selection of demonstrations are included below to highlight how the combined observation and model based products from MERSEA project (and from November 2009 MyOcean MCS) can be used in support to systematic indicator monitoring and 15 reporting. The variables and demonstrations are targeting: (i) global mean sea level; (ii) temperature and currents in the European Seas; and (iii) Arctic sea ice. They would predominantly contribute to the state monitoring and reporting in the context of DPSIR framework where Driver indicators (D) represent anthropogenic forcing of the marine environment, Pressure indicators $(P)$ represent pressures on the system 20 resulting from the drivers, State indicator (S) represent environmental condition, Impact indicators (I) represent the impact of the pressures on the environmental condition, and Response indicators $(\mathrm{R})$ represent the response of society and management to mitigate the impacts.

Moreover, following Hardman-Mountford and Huthnance (2006) complementary 25 information are added to these demonstrations. According to the policy relevance, data coverage and resolution, data sources and availability, analyses and interpretation, and limitations.
OSD

$7,121-141,2010$

Oceanography in support to indicator reporting

J. A. Johannessen et al.

Title Page

Abstract Introduction

Conclusions

Tables References

Figures

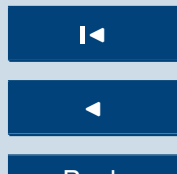

$\Delta \mathbf{I}$

Back

Close

Full Screen / Esc

Printer-friendly Version

Interactive Discussion 


\subsection{Sea level}

The sea level is a mature variable derived from two main observational data streams: the sea level stations dataset and the satellite altimetry dataset. Whereas the in-situ sea level measurements is a unique mean to provide the longest time-series of sea

5 level measurements dating back to late 1800, accurate estimation of the sea level trend and its associated spatial structure are estimated for the last 17 years thanks to satellite altimetry revealing a global mean rise of about $3.33 \mathrm{~mm} /$ years (see Fig. 2). OO has already organized the production and visualization of sea level trend indicators from altimetry at different space and time scale (AVISO web site: http://www.aviso. oceanobs.com/en/news/ocean-indicators/mean-sea-level/index.html).

In the past EEA used only in-situ data to estimate sea level trends for the last century. But starting from the last climate change and impacts report (http://www.eea.europa. eu/publications/eea_report_2008_4) EEA is now also including OO altimetry data.

- Policy relevance: global warming and sea level rise. Relevant to IPCC. Also relevant in the context of GEO/GEOSS and GMES objectives.

- Data coverage and resolution (spatial-temporal, precision, accuracy): the sea level trends (regional trend and global trend) are calculated from the along track T/P Jason $1 / 2$ series of mean sea surface observations. The data are corrected for seasonal variations, the inverse barometer effects. There is also a correction for Post-glacial rebound. For the global trend maps defined on a $1 / 3^{\circ}$ Mercator-grid the map combining all available altimeter data (see Le Traon et al., 1998 and Ducet et al., 2000) are used. For the Mediterranean and the Black Sea, regional products defined on a $1 / 8^{\circ}$ grid are used.

- Data sources and availability: altimetry from ERS-1/2, Topex/Poseidon, Geosat Follow-On, Envisat, Jason $1 / 2$ are systematically merged and used to establish a near 20 year consistent time series. Collaborative efforts between different groups (CLS, CNES, LEGOS, and INGV) are established in the frame of the

OSD

$7,121-141,2010$

Oceanography in support to indicator reporting

J. A. Johannessen et al.

Title Page

Abstract

\section{Full Screen / Esc}

Printer-friendly Version

Interactive Discussion 
MERSEA-IP and Boss4GMES FP6 projects funded by EU. A summary of the main results are found at http://www.aviso.oceanobs.com/html/actualites/indic/ $\mathrm{msl} /$ welcome_uk.html. Products from the Mediterranean have been developed as part of the EU MFSPP, MFSTEP and MOON projects. Examples of their use are available in Larnicol et al. (2002) and Pujol and Larnicol (2005). The Black Sea products are developed as part of the EU ECOOP project and details of the processing can be found in Dufau (2007).

- Analyses and interpretation: after correction for the inverse barometer effect, seasonal variations and glacial isostatic adjustment the sea level trend and its associated spatial structure are accurately estimated for the last 17 years revealing a global mean rise of about $3.33 \mathrm{~mm} / \mathrm{years}$. Only in combination with precise measurements of meltwater run-off from glaciers and ice sheets and heating of the ocean is it possible to offer a quantitative explanation to global and regional changes in sea level.

15 - Limitation: incomplete and more uncertain as one approach the coastal shallow water regions and in the ice covered seas of the Northern of Southern Hemispheres. Recently, a paper describing the estimation error was published in Ocean Science journal (Ablain et al., 2009).

\subsection{Temperature}

20 Temperature products from $\mathrm{OO}$ services are considered mature and provide high frequency and complete spatial coverage for the global ocean and the regional seas. In-situ sea surface temperature (SST) data are valuable to validate satellite data, increase the accuracy and provide, together with model analysis homogeneous 3 dimensional products. Presently EEA is using Sea Surface Temperature time-series in the climate change and assessment reports and an EEA indicator related to the Global and European Temperature (CSI 012) exists. Temperature related indicators answer policy-relevant questions such as: will the global average temperature increase

\section{OSD}

$7,121-141,2010$

Oceanography in support to indicator reporting

J. A. Johannessen et al.

\section{Title Page}

\section{Full Screen / Esc}

Printer-friendly Version

Interactive Discussion 
stay within the EU policy target $\left(2^{\circ} \mathrm{C}\right.$ above pre-industrial levels)? This question is related to the Council Decision (2002/358/EC) of 25 April 2002 and Decision No 280/2004/EC of the European Parliament and of the Council of 11 February 2004.

An example of a possible temperature indicator, consisting of the basin mean SST anomaly has been calculated for the Mediterranean Sea using the daily analysis of the Mediterranean Forecasting System (MFS) compared with the MEDATLAS climatology covering the period 2001-today, has been calculated (see Fig. 1 of Coppini et al., 2009).

- Policy relevance: global warming, climate and environmental change. Relevant to IPCC and EEA, but also in the context of sustainable ecosystem management (ICES). Specifically included in HELCOM and UNEP/MAP lists of indicators for the Baltic and Mediterranean Seas. Also relevant for GEO/GEOSS and GMES.

\section{- Data coverage and resolution (spatial-temporal, precision, accuracy):}

satellite derived SST are available as twice-daily snapshot observations with a resolution of $1 \mathrm{~km}$. They are limited by presence of clouds. Through temporal and spatial averaging for cloud removals the SST fields are available at weekly and monthly timescales with resolution of $5-10 \mathrm{~km}$. SST absolute accuracy is $\sim 0.5^{\circ} \mathrm{C}$, while in general the relative accuracy is better than $\sim 0.1^{\circ} \mathrm{C}$. Daily SST retrievals from passive microwave sensors at $25 \mathrm{~km}$ spatial are also obtained independent of cloud cover. The satellite sensor stability is a critical issue in order to establish accurate long term SST time series. A climatologic data base also exist with a resolution of 1 degree. Data continuity and coverage from satellite observations looks satisfactory towards 2020.

- Data sources and availability: quality controlled satellite SST fields are available in near real time from the GHRSST server combining polar orbiting AVHRR, AATSR, MODIS and AMSR-E sensors with geostationary sensors and surface buoys. Regional products are delivered operationally for different European regional seas and will be continued in the SST TAC in MyOcean. Argo floats, now reached 3300 , give quality controlled temperature profiles from the surface to

OSD

$7,121-141,2010$

Oceanography in support to indicator reporting

J. A. Johannessen et al.

Title Page

Abstract Introduction

Conclusions

Tables References Figures 14 $\Delta$

4

\section{Full Screen / Esc}

Printer-friendly Version

Interactive Discussion 
about $2000 \mathrm{~m}$. They are available in near real time from the Coriolis server. XBTs from VOS complements these sources of near real time temperature data. Other temperature observations from moored or drifting buoys and research vessels are mostly available in off-line modes. MyOcean Monitoring and Forecasting Services (MFCs) provide daily 3-D fields of ocean temperature consisting of model analyses and forecast for the European Seas and the Global Ocean.

- Analyses and interpretation: through GHRSST and MEDSPIRATION a more consistent Level 4 temperature product is emerging from the satellite SST databases, the so-called Functional SST. Long time series will reveal trends in the temperature field. Observed temperature increase may indicate global warming, although it cannot explain the cause in isolation. Three dimensional products (synthesis) based on in situ data are produced by the Coriolis Centre as part of the MyOcean In-Situ TAC.

- Limitations: cloud cover limits the availability and quality of satellite SST fields derived from Infrared Radiometers.

\subsection{Sea ice}

Recent observed decadal changes in the extent of Arctic sea ice provide early evidence of global climate warming. The indicators derived from the Ice SDTE describe the trends of the area covered by the ice (record low summer ice area in the Arctic time-series and trends, ice area and extent time-series and trends and anomalies). Examples are available at http://www.mersea.eu.org/lndicators-with-B4G.html and http://www.arctic-roos.org. Sea ice area fluxes through the Fram Strait have been manually calculated for each pair of SAR images where ice drift was retrieved and compiled into monthly fluxes as shown in Fig. 3. The plot of monthly mean area flux shows a pronounced maximum in the winter months and a minimum in the summer months. There is also a significant interannual variability.
OSD

$7,121-141,2010$

Oceanography in support to indicator reporting

J. A. Johannessen et al.

\section{Title Page}

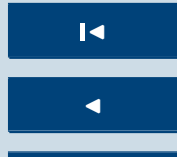

\section{Full Screen / Esc}

Printer-friendly Version

Interactive Discussion 
- Policy relevance: global warming, climate and environmental change. Relevant to IPCC and the international Arctic Marine Assessment Program (AMAP). Also relevant in the context of GEO/GEOSS and GMES objectives. Specifically included in HELCOM lists of indicators for the Baltic. Increased human activities in polar regions (i.e. fisheries, oil and gas exploitation, sea transportation in the Northern Sea Route) with risks of accidents and damage to a very vulnerable environment require improved monitoring and forecasting systems.

- Data coverage and resolution (spacial-temporal, precision, accuracy): long time ( 30 years) series exist with spatial resolution in the order of $25-50 \mathrm{~km}$. High resolution (order $1 \mathrm{~km}$ ) sea ice fields are also available since 1990. Sea ice concentration and extent are accurate to about $5 \%$, while sea ice motion and flux estimates are around $10 \%$ or better. The accuracy of ice thickness estimates is less, but will improve with the launch of Cryosat-2 in 2010. Operational downstream services for offshore industry, shipping and safety in polar regions provide regular iceberg detection and sea ice type, extent and deformation monitoring at fine spatial resolution $(\sim 50-100 \mathrm{~m})$ that is only feasible with spaceborne SAR. Data continuity and coverage from satellite observations looks satisfactory towards 2020 .

- Data sources and availability: passive and active satellite microwave observations are the only source of continuous information about sea ice extent, concentration, type and drift. The sparseness of non-space observing systems and the high cost of operating such systems in polar regions (i.e. aircraft, icebreakers, helicopters, buoy systems, etc.) enhance the importance of satellite observing systems in these regions. In particular the contribution from SAR observations is highly needed for better understanding of sea ice deformation processes and safer sea transportation and offshore operations at high latitudes. In addition Cryosat-2 will provide new and highly needed observations of sea ice thickness measurements.

OSD

$7,121-141,2010$

Oceanography in support to indicator reporting

J. A. Johannessen et al.

Title Page

Abstract Introduction

Conclusions

Tables References

Figures

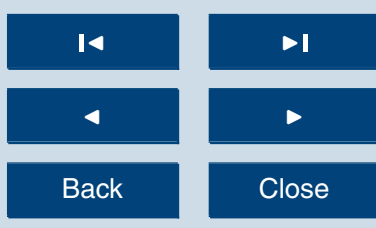

Full Screen / Esc

Printer-friendly Version

Interactive Discussion 
- Analyses and interpretation: regular information products such as ice types, concentration, thickness, roughness, ridges, leads, polynyas, fast ice, ice motion, presence of iceberg are produced from satellite observations and delivered in near-real time. Within the downstream services these and other value-added products can be tailored to any specific regions and user requirements having special request for spatial and temporal coverage as well as information product accuracies such as for ice motion, thickness and probability density function of ridges.

- Limitation: there are presently very few high quality precise observations of ice thickness, an essential climate indicator.

\subsection{Currents}

The potential of using upper ocean currents for indicator reporting is now emerging thanks to implementation and execution of OO and MCS. Currents are moreover key to estimation of volume and heat transports as well as distribution and spreading of 15 pollutant material. In Fig. 4 a time series of the Norwegian horse mackerel catches (1977-2006) are shown versus modelled influx of Atlantic Water to the Norwegian Sea/North Sea in the first quarter of every year from 1976-2007. When the reported catch of horse mackerel in the Norwegian Economic Zone (NEZ) is compared with the modelled influx of Atlantic water to the North Sea (represented for the first quarter) and interesting high correlation is found, in particular from 1987 to 2000 (Iversen et al., 2002). This high correlation has also been used to predict the catch level in NEZ since 1997 based on the modelled influx with fairly promising results when compared to the actual catches except for year 2000.

These findings are very interesting and suggest that for the horse mackerel stock 25 in the North Sea the abundance, catch reports and volume fluxes of Atlantic are correlated. This correlation, in turn, is allowing catch prediction to a surprising degree of accuracy when compared to the actual reported catches. More work is necessary

OSD

$7,121-141,2010$

Oceanography in support to indicator reporting

J. A. Johannessen et al.

Title Page

Abstract Introduction

Conclusions

Tables References

Figures

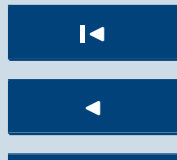

$\Delta$

Back

$\checkmark$

Close

Full Screen / Esc

Printer-friendly Version

Interactive Discussion 
to conclude whether this method has some merit for fishery stock prediction and management and consequently for indicator reporting.

- Policy relevance: global warming, climate and environmental change. Relevant to IPCC. Relevant for GEO/GEOSS and GMES. Specifically included in HELCOM

5 lists of indicators for the Baltic, but also indirectly of importance for the chlorophyll-a in transitional, coastal and marine waters and ecosystem quality objectives on stratification as specified UNEP/MAP and OSPAR. EMSA is authorized to provide technical and scientific assistance to the European Commission and Member States in the proper development and implementation of EU legislation on maritime safety, pollution by ships and security on board ships.

- Data coverage and resolution (spatial-temporal, precision, accuracy): altimeter based global surface geostrophic current is obtained at spatial and temporal resolutions of about $20-30 \mathrm{~km}$ every 10 days. These observations are accurate to about $3-4 \mathrm{~cm} / \mathrm{s}$. They are in combination with models used to obtain transport estimates with an accuracy of about $10 \%$. Moored and ship observations with ADCP are scattered in space, but may have fine temporal resolution with a very good accuracy of typically $\sim 5 \mathrm{~cm} / \mathrm{s}$. HF-radars, mostly located in coastal vicinity, and only satisfactorily in numbers and coverage along the south and east coast of US, provide currents with an accuracy typically of $0.1 \mathrm{~m} / \mathrm{s}$. Surface drifters are providing reasonable coverage in selected regions.

- Data sources and availability: radar altimetry is the only satellite source for global observations of surface geostrophic current. Surface currents in coastal regions are obtained by land-based HF radar (Doppler-shifted reflections off surface waves). This technique is also possible from satellite synthetic aperture radar (SAR) by utilizing the dual and single antenna Doppler shift measurements (Johannessen et al., 2008). In-situ measurements use moored current meters, most commonly now ADCPs which obtain a profile through part of the water

Oceanography in support to indicator reporting

J. A. Johannessen et al.

Title Page

Abstract Introduction

Conclusions

Tables References Figures

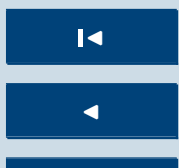

Back

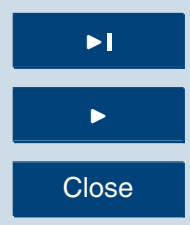

Full Screen / Esc

Printer-friendly Version

Interactive Discussion 
column. In situ current measurements are extremely scarce, and often irregular in time and space. In addition satellite tracked surface drifters provide estimates of surface current. Satellite altimetry provides the best global and repeat, near real time, all weather sea level slope measurements from which surface geostrophic current are derived. Global estimates of 3-D currents are available from ocean models. Measures of ocean currents are also obtained from the drift of Argo floats, albeit with low time and space resolution. MyOcean MFCs provide daily 3-D fields of ocean currents consisting of model analyses and forecast for the European Seas and the Global Ocean.

- Analyses and interpretation: the optimum estimates of ocean currents come from ocean models with data assimilation such as now routinely provided in the MyOcean project.

- Limitation: broad scale coverage of in situ current measurements is extremely limited. Models provide spatial coverage, with limited accuracy, and often lacks independent validation data. The lack of precise knowledge of the mean dynamic topography limits our capability to accurately estimate the total surface current from altimetry with sufficient spatial and temporal coverage. This is expected to improve with the launch of GOCE in March 2009. Model validations are also limited. New capabilities with satellite interferometry is also emerging.

\subsection{Chlorophyll-a}

Satellite Chlorophyll-a concentration fields are well developed satellite products and they are now widely available at daily and monthly time scales in all European coastal/shelf and open ocean waters (higher temporal resolution can be achieved in southern European regional seas under more frequent cloud free 25 conditions). Satellite Chlorophyll-a might eventually be used in support to the further development of the EEA CSI023 Chl-a indicator based on in-situ datasets. In so doing the spatial information derived from these satellite data would improve
OSD

$7,121-141,2010$

Oceanography in support to indicator reporting

J. A. Johannessen et al.

Title Page

Abstract Introduction

Conclusions

Tables References

Figures

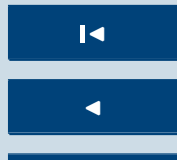

$\Delta$

Back

Close

Full Screen / Esc

Printer-friendly Version

Interactive Discussion
$>$

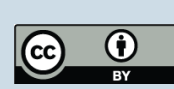


its representativeness for the different European coastal waters. The objective of the EEA CSI023 Chlorophyll-a indicator reporting (http://themes.eea.europa.eu/IMS/ IMS/ISpecs/ISpecification20041007132031/full_spec) is to demonstrate the effects of measures taken to reduce discharges of nitrogen and phosphate on coastal 5 concentrations of phytoplankton expressed as Chlorophyll-a. This is consequently an indicator of eutrophication. Hence, it is relevant for all the EU Directives aimed at reducing the loads and impacts of nutrients (i.e., Nitrates Directive (91/676/EEC), Urban Waste Water Treatment Directive (91/271/EEC)).

\subsection{Salinity}

10 Using $\mathrm{OO}$ products, a salinity indicator could be developed to monitor the changes in salinity all over the European Seas. Such an indicator will support indirect estimates of changes in evaporation-precipitation, ice sheet and glacier melting and river-run-off. The launch of the SMOS (November 2009) and Aquarius (2010) satellites will add highly needed new insight on global scale sea surface salinity conditions and variations, in particular in the warmer tropical and equatorial ocean basins where the sensitivity of the L-band microwave radiometer is good. Although $\mathrm{OO}$ products are available, the salinity appears less ready for the development of a new indicator at pan-European level because its correlation with environmental aspects is not yet well recognised in all European marine areas. The expected relationship to freshwater runoff, which yet has to be measured and reported systematically for all European Seas, is in particular a limiting factor.

\subsection{Transparency}

Transparency would be a very interesting indicator. However, more effort is needed to relate and combine transparency to in-situ measurements such as from using

25 Secchi disk. Transparency is suitable to derive indicators in support the water quality monitoring (i.e. European Directive 76/160/EEC on Bathing Water Quality). It can be

OSD

7, 121-141, 2010

Oceanography in support to indicator reporting

J. A. Johannessen et al.

\section{Title Page}

Abstract

\section{Full Screen / Esc}

Printer-friendly Version

Interactive Discussion 
estimated with support from satellite spectrometry by estimating the $K(490)$ values for Case I and Case II water flags. Due to the different morphological and hydrological properties of European regional areas, it is recommended to arrange the indicator similar to the Chlorophyll-a indicator.

\section{Conclusions}

Indicators have and will play a vital part in focusing and illuminating the significance of environmental change and the progress to sustainable development. In consideration of the step-by-step approach in selection and development of indicators the following five criteria are commonly used:

10 - clearly defined,

- linked to policies,

- easy to understand and interpret (scientifically reliable and significant),

- limited in number,

- based on acknowledged (official) and accessible data.

15 Some of the key state variables produced from OO services are considered mature for contribution to the development of indicator reporting as demonstrated in this paper. In particular this paper emphasizes sea level, temperature, sea ice and currents as the most appropriate quantities to be turned into indicators with the use of OO systems (see also http://www.mersea.eu.org/Indicators-with-B4G.html).

$20 \quad$ According to Mee et al. (2009) the two policy pillars which in particular are driving indicator development for the comprehensive and integrated management of human activities are: (a) the sustainable use of ecosystem goods and services (e.g. as outlined in the Marine Green Paper), and (b) the maintenance of ecosystem integrity (e.g. as outlined in the Marine Strategy Directive (MSD)). The European Union is strongly
OSD

7, 121-141, 2010

Oceanography in support to indicator reporting

J. A. Johannessen et al.

Title Page

Abstract

Introduction

Conclusions

Tables

References

Figures

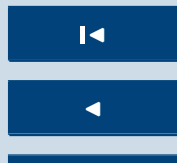

$\Delta$

Back

Close

Full Screen / Esc

Printer-friendly Version

Interactive Discussion 
committed to the protection of oceans and seas and adopted in 2008 a strategy for the protection and conservation of the marine environment including several discussion papers and the Marine Strategy Directive (MSD). The objective of the Directive is to achieve good environmental status of the EU's marine waters by 2021 and to 5 protect the resource base that has a huge impact on marine-related economic and social activities. The Directive establishes European Marine Regions on the basis of geographical and environmental criteria. Each Member State is required to develop strategies for their marine waters comprising a detailed assessment of the state of the environment, a definition of good environmental status at regional level and the

10 establishment of clear environmental targets and monitoring programmes. In view of this Chlorophyll-a, salinity and transparency variables should moreover be selected for development into indicators as they are all of importance for water quality and as such highly relevant vis-à-vis the key driving policy pillars (Mee et al., 2009).

Acknowledgements. Financial support for our work was provided by the EU project 15 MERSEA (Marine Environment and Security for the European Area, Contract number: SIP3-CT-2003-502885), BOSS4GMES (Building Operational Sustainable Services for GMES, contract number: FP6-2005-SPACE-1-030966) and by the European Topic Center for Water (ETC-W).

\section{References}

20 Ablain, M., Cazenave, A., Valladeau, G., and Guinehut, S.: A new assessment of the error budget of global mean sea level rate estimated by satellite altimetry over 1993-2008, Ocean Sci., 5, 193-201, 2009, http://www.ocean-sci.net/5/193/2009/.

Bahurel, P., Adragna, F., Bell, M., Jacq, F., Johannessen, J. A., Le Traon, P.-Y., Pinardi, N., and She, J.: MyOCEAN-A European example of a Post-GODAE initiative, online available at: http://www.godae.org/modules/documents/documents/Proceedings-GFS-2008.pdf, 2009.

Coppini, G., Pinardi, N., Lyubartsev, V., Soulat, F., Larnicol, G., Guinehut, S., Pujol, I., Johannessen, J. A., Fratianni, C., Tonani, M., Marullo, S., Loewe, P., Santoleri, R., Colella,

OSD

$7,121-141,2010$

Oceanography in support to indicator reporting

J. A. Johannessen et al.

\section{Title Page}

Abstract

Conclusions

References

Tables

Figures

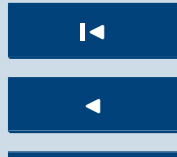

Back

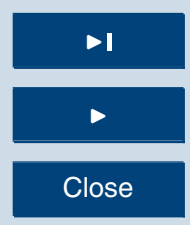

Full Screen / Esc

Printer-friendly Version

Interactive Discussion 
S., and Volpe, G.: Operational Oceanography and European Environment Agency indicators, Proceedings EuroGOOS, submitted, 2008.

Desaubies, Y.: The Mersea Project - Introduction to the Ocean Science Special Issue June 18, 2009.

5 EEA-Impacts of Europe's changing climate: An indicator-based assessment, EEA Report No. 2, 2004.

EEA-led EMMA OO Workshop (EEA, Copenhagen, 23-24 October 2006): "Connecting operational oceanography with the European Marine Strategy and EEA assessments" - Final report: http://circa.europa.eu/Public/irc/env/marine/library?l=/workingsgroups/ europeansmarinesmonitori/eea-led_2006-2007/operational_oceanography/4_-_report/ final_201206pdf/_EN_1.0_|\&a=d, 2006.

Hammond, A., Adriaanse, A., Rodenburg, E., Bryant, D., and Woodward, R.: Environmental indicators: a systematic approach to measuring and reporting on environmental policy performance in the context of sustainable development, World Resources Institute,

15 Washington, DC, 1995.

Hardman-Mountford, N. J. and Huthnance, J. M.: The Development of useful indicators for marine processes and climate (MPC) and u nderwater sound, Prepared for GOOS Action Group of the Interagency Committee for Marine Science and Technology (IACMST), March 2006.

20 Iversen, S., Skogen, M. D., and Svendsen, E.: Availability of horse mackerel (Trachurus trachurus) in the north-eastern North Sea, predicted by the transport of Atlantic water, Fish. Oceanogr., 11(4), 245-250, 2002.

Johannessen, J. A., Chapron, B., Collard, F., Kudryavtsev, V., Mouche, A., Akimov, D., and Dagestad, K.-F.: A model of combined backscatter and Doppler shifts for surface velocity estimation from SAR images, Geophys. Res. Lett., 35, L22608, doi:10.1029/2008GL035709, 2008.

Mee, L. D., Jefferson, R., Laffoley, D. d'A., and Elliott, M.: How good is good? Human values and Europe's proposed Marine Strategy Directive, Mar. Pollut. Bull., 56(2), 187-204, 2008.

Smeets, E. and Weterings, R.: Environmental Indicators: Typology and Overview, online available at: http://www.eea.europa.eu/publications/TEC25/tech_25_text.pdf, 1999.

Technical Report 25, European Environment Agency, Copenhagen, online available at: http: //reports.eea.eu.int:80/TEC25/en/tech25text.pdf, 1999.

OSD

7, 121-141, 2010

Oceanography in support to indicator reporting

J. A. Johannessen et al.

\section{Title Page}

Abstract

Introduction

Conclusions

References

Tables

Figures

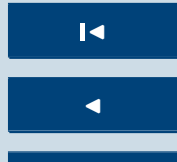

$\Delta$

Back

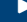

Close

Full Screen / Esc

Printer-friendly Version

Interactive Discussion 
Table 1. Key state variables available from observations and models together with higher level derived products produced from the operational oceanography systems.

\begin{tabular}{|c|c|c|c|}
\hline \multirow{2}{*}{$\begin{array}{l}\text { State } \\
\text { Variables }\end{array}$} & \multicolumn{2}{|c|}{ Products from } & \multirow{2}{*}{$\begin{array}{l}\text { Value-added products including } \\
\text { long-time series trends }\end{array}$} \\
\hline & Observations & Models & \\
\hline Sea Level & $x$ & $x$ & $\begin{array}{l}\text { Annual to decadal sea level } \\
\text { change, global and regional }\end{array}$ \\
\hline Temperature & $x$ & $x$ & $\begin{array}{l}\text { Upper layer heat content and SST } \\
\text { Mixed layer depth }\end{array}$ \\
\hline Sea ice & $x$ & $x$ & $\begin{array}{l}\text { Ice cover, concentration, mass, } \\
\text { thickness, motion, deformation } \\
\text { and volume fluxes }\end{array}$ \\
\hline Currents & $x$ & $x$ & $\begin{array}{l}\text { Transports (volume, } \\
\text { heat and salt) }\end{array}$ \\
\hline Chlorophyll & $x$ & $x$ & $\begin{array}{l}\text { Relevant for water quality } \\
\text { Mostly derived from satellite } \\
\text { observations }\end{array}$ \\
\hline Salinity & $x$ & $x$ & $\begin{array}{l}\text { Freshwater content, } \\
\text { Mixed layer depth }\end{array}$ \\
\hline Transparency & $x$ & $x$ & $\begin{array}{l}\text { Secchi depth, mixed } \\
\text { layer depth }\end{array}$ \\
\hline
\end{tabular}

Oceanography in support to indicator reporting

J. A. Johannessen et al.

Title Page

Abstract

Conclusions

Tables

14

4

Back

Introduction

References

Figures

Full Screen / Esc

Printer-friendly Version

Interactive Discussion 


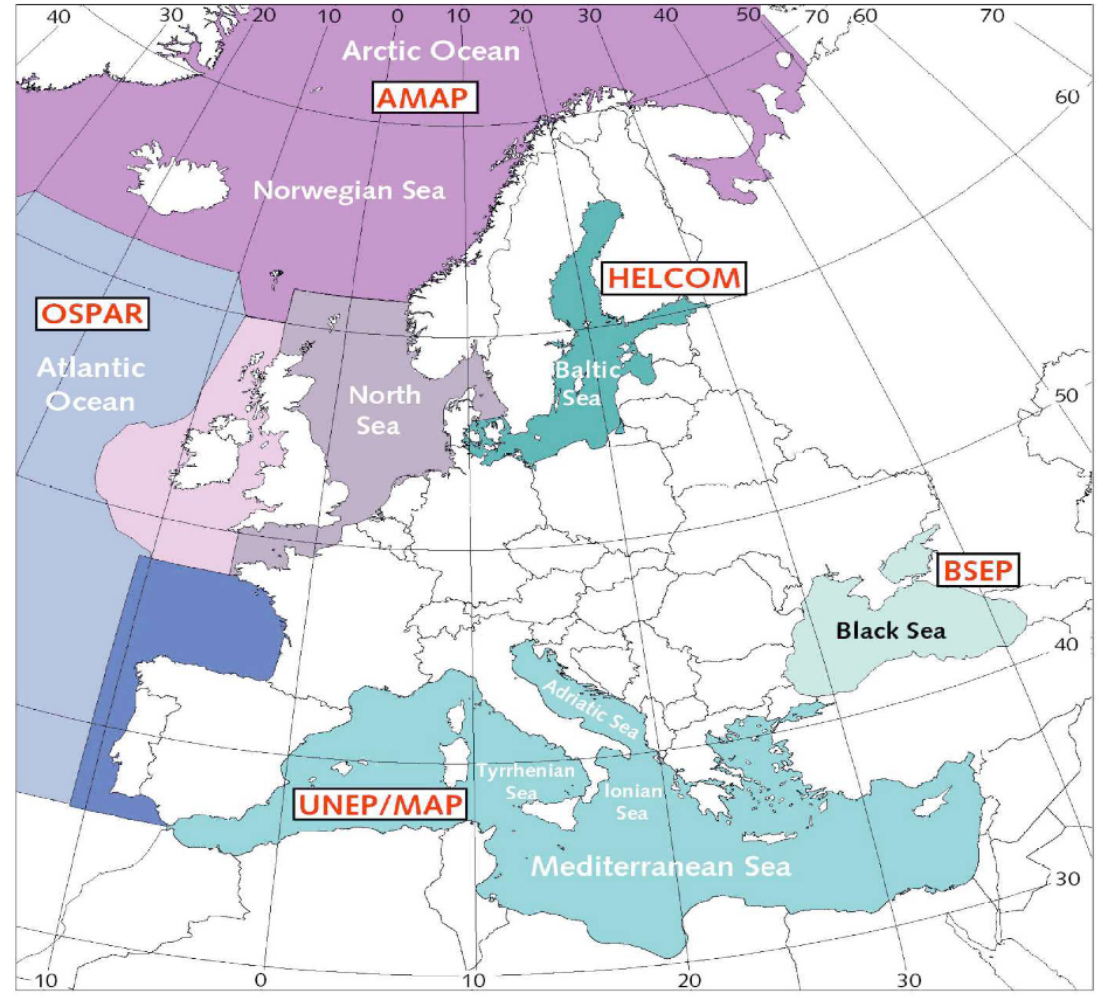

Fig. 1. The European marine environment defined into regions of targeted interest and responsibility by the conventions including: BSEP for the Black Sea, UNEP/MAP for the Mediterranean Sea, OSPAR for the Atlantic Ocean and North Sea, HELCOM for the Baltic Sea and AMAP for the Norwegian, Greenland, Iceland and Barents Seas and Arctic Ocean.
OSD

$7,121-141,2010$

Oceanography in support to indicator reporting

J. A. Johannessen et al.

Title Page

Abstract

Introduction

Conclusions

References

Tables

Figures

14

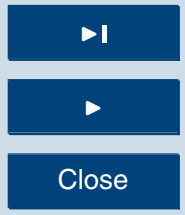

Back

Close

\section{Full Screen / Esc}

Printer-friendly Version

Interactive Discussion 


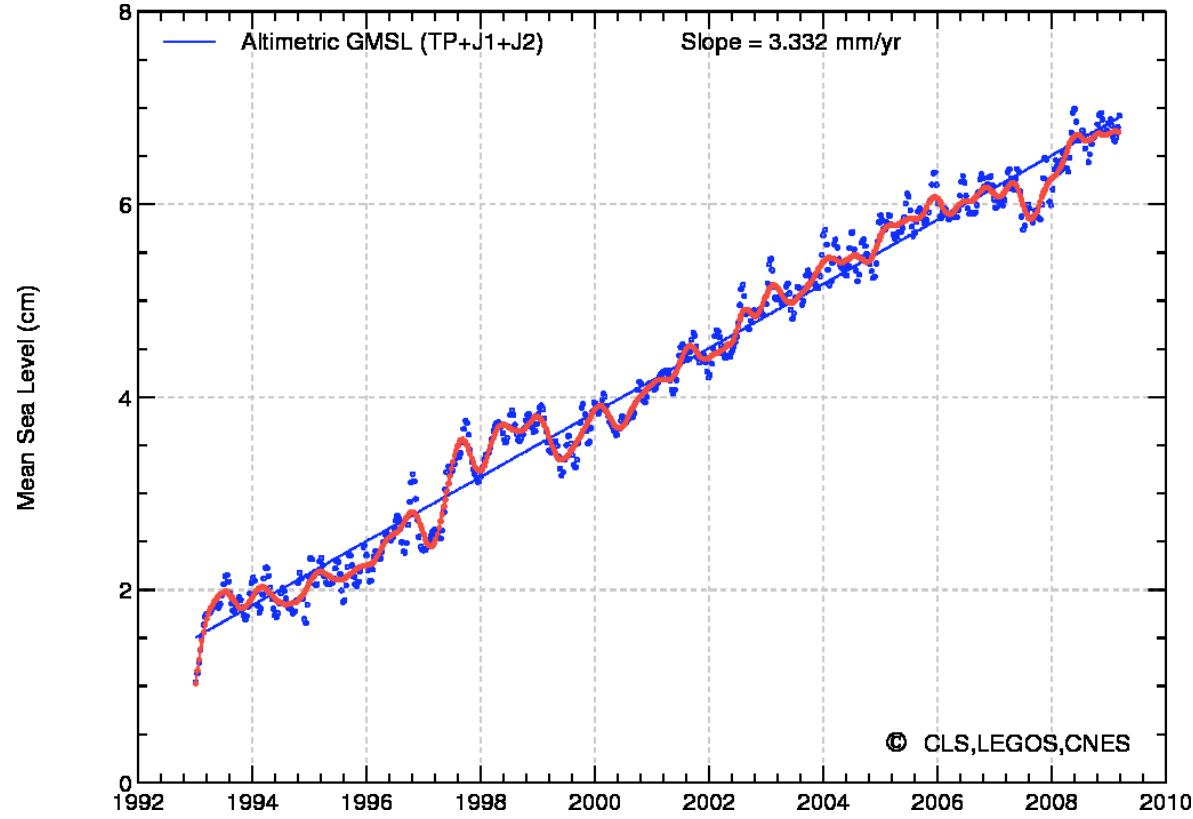

\section{Oceanography in support to indicator reporting}

J. A. Johannessen et al.

Title Page

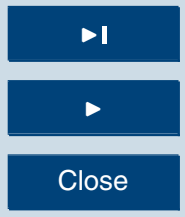

Fig. 2. Global mean sea level since October 1992 as seen by the altimetry satellites. Seasonal variations have been removed. These data are also corrected from Inverse barometer effects and the Glacial Isostatic Adjustment is applied. (Produced by Cnes/CLS/Legos EGOS/CNES.)

Interactive Discussion 
OSD

$7,121-141,2010$

Oceanography in support to indicator

reporting

[ 2004 [ $2005=2006 \square$

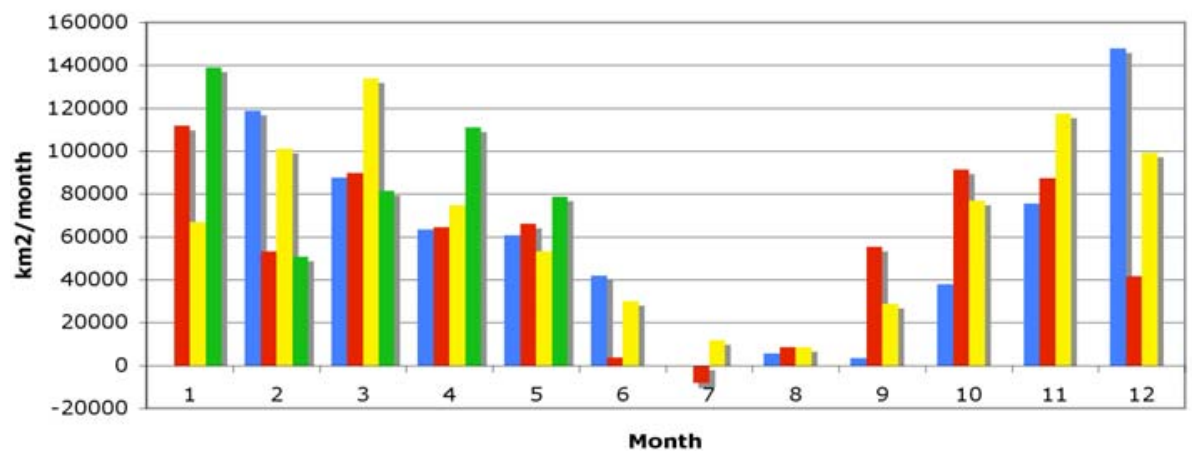

Fig. 3. Monthly ice area fluxes through the Fram Strait derived from SAR observations from the years 2004 (blue), 2005 (red), 2006 (yellow) and 2007 (green). The colour scale is marked in the plot. (Courtesy S. Sandven, Arctic ROOS chair.)

\section{J. A. Johannessen et al.}

\section{Title Page}

Abstract

Introduction

Conclusions

References

Tables

Figures

14

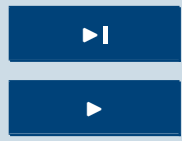

Back

Close

\section{Full Screen / Esc}

Printer-friendly Version

Interactive Discussion 


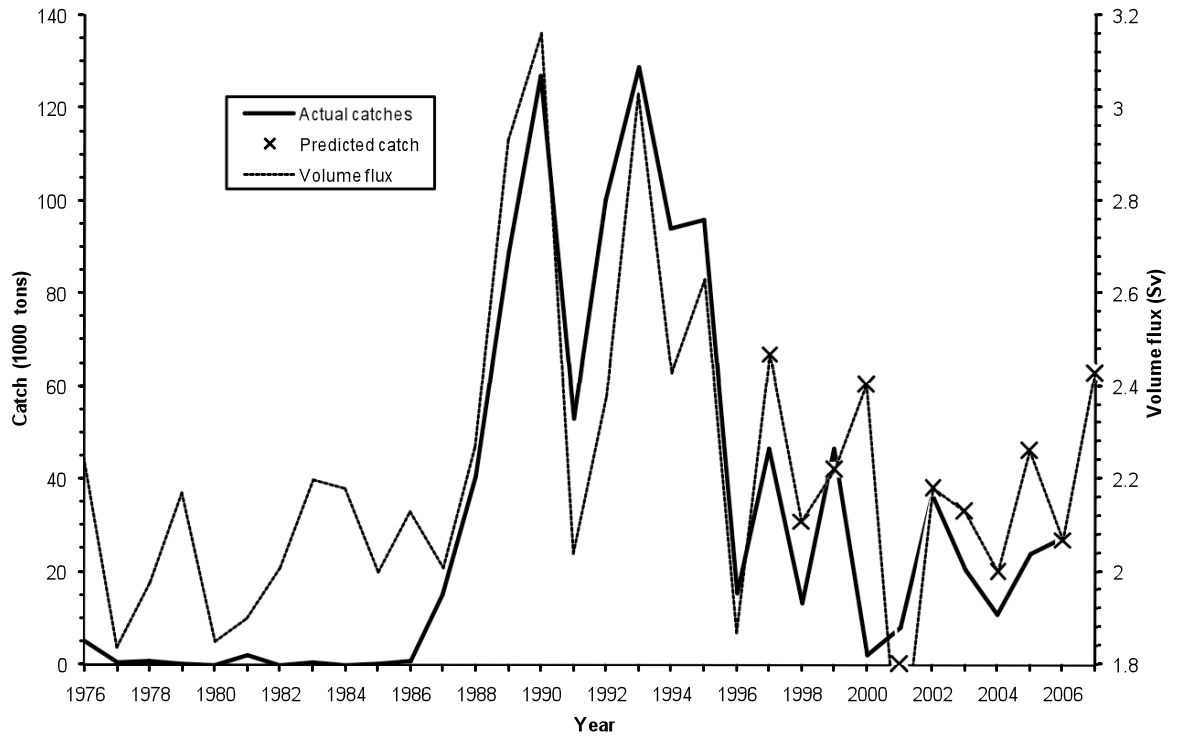

Fig. 4. Norwegian horse mackerel catches (1977-2006) versus modelled influx of Atlantic Water to the Norwegian Sea/North Sea in the first quarter of every year from 1977-2007. Note also that predicted catches are given from 1997-2007. (Courtesy E. Svendsen, IMR.)

\section{Oceanography in support to indicator reporting}

\section{J. A. Johannessen et al.}

Title Page

\section{Abstract}

Introduction

Conclusions

References

Tables

Figures
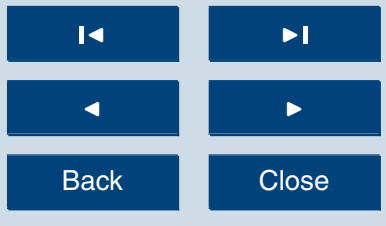

Back

Full Screen / Esc

Printer-friendly Version

Interactive Discussion 